\title{
County Differences in Mortality among Foreign-Born Compared to Native Swedes 1970-1999
}

\author{
Björn Albin, ${ }^{1,2}$ Katarina Hjelm, ${ }^{1}$ Jan Ekberg, ${ }^{3}$ and Sölve Elmståhl ${ }^{2}$ \\ ${ }^{1}$ School of Health and Caring Sciences, Linnaeus University, 35195 Växjö, Sweden \\ ${ }^{2}$ Centre of Labour Market Policy Research (CAFO), School of Business and Economics, Linnaeus University, 35195 Växjö, Sweden \\ ${ }^{3}$ Department of Health Sciences, Division of Geriatric Medicine, Lund University, 22100 Lund, Sweden \\ Correspondence should be addressed to Björn Albin, bjorn.albin@lnu.se
}

Received 9 February 2012; Accepted 16 July 2012

Academic Editor: Rosa Benato

Copyright (๑) 2012 Björn Albin et al. This is an open access article distributed under the Creative Commons Attribution License, which permits unrestricted use, distribution, and reproduction in any medium, provided the original work is properly cited.

Background. Regional variations in mortality and morbidity have been shown in Europe and USA. Longitudinal studies have found increased mortality, dissimilarities in mortality pattern, and differences in utilization of healthcare between foreign- and nativeborn Swedes. No study has been found comparing mortality among foreign-born and native-born Swedes in relation to catchment areas/counties. Methods. The aim was to describe and compare mortality among foreign-born persons and native Swedes during 1970-1999 in 24 counties in Sweden. Data from the Statistics Sweden and the National Board of Health and Welfare was used, and the database consisted of 723,948 persons, 361,974 foreign-born living in Sweden in 1970 and aged 16 years and above and 361,974 matched Swedish controls. Results. Latest county of residence independently explained higher mortality among foreignborn persons in all but four counties; OR varied from 1.01 to 1.29. Counties with a more rural structure showed the highest differences between foreign-born persons and native controls. Foreign-born persons had a lower mean age (1.0-4.3 years) at time of death. Conclusion. County of residence influences mortality; higher mortality is indicated among migrants than native Swedes in counties with a more rural structure. Further studies are needed to explore possible explanations.

\section{Introduction}

Earlier studies have shown that mortality and morbidity vary in different parts of a country both in European countries and the US [1-4]. To our knowledge no study has compared mortality among foreign-born and native-born Swedes in relation to catchment areas such as counties. Geographical variation in mortality is due to influencing factors, in childhood and in adulthood, such as social class, employment status and social and physical environment [5], and unequal utilization of healthcare. Districts with high or low mortality could be identified in the UK [1]. Another investigation showed an association between area of residence and stomach cancer or stroke [3]. In Italy higher mortality for men was found in the north of the country compared to the south but the reversed pattern was evident for women [2].

Previous longitudinal studies of mortality, morbidity, and heath care utilization among foreign- and native-born Swedes during 1970-1999 have found increased mortality, dissimilarities in mortality pattern, and differences in utilization of hospital care [6-8]. The results showed higher mortality and a 2.5 to 2.8 years lower mean age at time of death for foreign-born persons compared to the Swedish controls. The mortality pattern showed a significantly higher number of deaths among foreign-born from neoplasm, diseases of the circulatory system, symptoms, signs, and ill-defined conditions, and injury and poisoning, according to the International Classification of Diseases, ranging from 1.0\% to 5.3\% higher prevalence [7]. A tendency towards less healthcare utilization among migrants, especially men, as regards to the diagnosis groups symptoms, signs, and ill-defined conditions and injury and poisoning has been found [8].

In Sweden, geographical differences in mortality and morbidity of the total population have been described [9, 10]. The average lifetime was found to be longer in the southern part of Sweden. Cancer was more frequent in the three largest cities, whereas accident as cause of death was more often found in rural areas. Differences in utilization 
TABLE 1: Excluded and analysed persons related to country of birth, sex, and age.

\begin{tabular}{|c|c|c|c|c|c|c|c|c|c|c|}
\hline & \multicolumn{3}{|c|}{ Excluded male persons } & \multicolumn{2}{|c|}{ Analysed male persons } & \multicolumn{3}{|c|}{ Excluded female persons } & \multicolumn{2}{|c|}{ Analysed female persons } \\
\hline & $n$ & $\begin{array}{c}\text { Mean } \\
\text { age } 1970\end{array}$ & $\begin{array}{l}\text { Proportion } \\
\text { excluded \% }\end{array}$ & $n$ & $\begin{array}{l}\text { Mean } \\
\text { age } 1970\end{array}$ & $n$ & $\begin{array}{c}\text { Mean } \\
\text { age } 1970\end{array}$ & $\begin{array}{l}\text { Proportion } \\
\text { excluded \% }\end{array}$ & $n$ & $\begin{array}{c}\text { Mean age } \\
1970\end{array}$ \\
\hline Swedish & 54729 & 31.5 & 24.5 & 168702 & 39.4 & 36578 & 32.2 & 15.9 & 193272 & 42.0 \\
\hline Denmark & 3285 & 34.8 & 17.4 & 15627 & 43.0 & 2054 & 34.4 & 13.0 & 13795 & 44.1 \\
\hline Finland & 27193 & 29.3 & 30.8 & 60959 & 34.8 & 18035 & 29.9 & 17.9 & 82544 & 37.4 \\
\hline Norway/Iceland & 3654 & 32.9 & 21.6 & 13236 & 45.7 & 2875 & 33.4 & 11.4 & 22413 & 48.0 \\
\hline Yugoslavia & 3518 & 32.6 & 23.3 & 11598 & 31.8 & 2519 & 33.1 & 23.2 & 8362 & 31.1 \\
\hline Poland & 462 & 35.4 & 9.8 & 4253 & 44.6 & 354 & 35.2 & 6.7 & 4925 & 44.6 \\
\hline Germany & 2613 & 34.6 & 15.5 & 14291 & 41.6 & 2123 & 36.4 & 9.7 & 19675 & 45.0 \\
\hline Other European & 10442 & 34.2 & 23.2 & 34510 & 42.0 & 6577 & 34.9 & 18.9 & 28229 & 46.0 \\
\hline Non-European & 3496 & 32.4 & 19.9 & 14035 & 45.0 & 1966 & 33.9 & 13.1 & 13081 & 51.7 \\
\hline Stateless/unknown & 66 & 30.6 & 25.5 & 193 & 50.2 & 75 & 30.7 & 23.2 & 248 & 55.8 \\
\hline Total & 109458 & & 100 & 337404 & & 73156 & & & 386544 & \\
\hline
\end{tabular}

of healthcare in different age groups among elderly persons have been studied [11]. The study found fewer days in hospital care and fewer visits to a general practitioner in the oldest age group, 80+, during the last year before death.

Swedish society has changed during the last century due to international migration and foreign-born people living in Sweden constituted 200411.5 percent of the total population [12]. The population of foreign-born in Sweden shows a great mixture of different nationalities but is dominated by labour migrants from the Nordic countries, especially Finland, and European countries such as the former Yugoslavia, Germany, and Poland [12].

The differences in health found in previous investigations, among foreign-born and native Swedes, could be a general pattern or vary in different parts of Sweden. Whether differences in healthcare services between county council areas are related to mortality among foreign born is unknown. In accordance with the Swedish Health and Medical Services Act, there should be no differences in healthcare services [13]. Earlier findings and the lack of studies in the area of geographical differences in mortality among foreignborn and native population warrant further studies.

The aim of this study was to describe and compare the county distribution of mortality among foreign- and Swedish-born persons during the years 1970-1999. The pattern will be discussed in relation to gender, year of birth, and age at death, testing the null hypothesis that no county differences in mortality exist between foreign-born and native Swedes.

\section{Material and Methods}

Data from Statistics Sweden (SCB) and the National Board of Health and Welfare Centre for Epidemiology covering the period 1970-1999 was analysed. The study population consisted of all 361,974 foreign-born persons aged 16 years and upward who were registered as living in Sweden in 1970, together with 361,974 matched Swedish controls for each person. The control was matched and was similar in age ( \pm 3 year), sex, occupation, type of employer, and lived in the same county in 1970. Type of employment was divided into three groups (government, municipal, or other employer). Occupation was coded according to the Nordic Occupation Classification System (NYK), and county represented all the 24 county council areas in Sweden. This data relates to the situation on 1 November 1970 and was taken from the National Census of 1970, which was a total census and checked against the National Population Register (RTB), which included data up to 31 December 1999. Each person was given a code if they were deceased, still living in Sweden, had emigrated, or if no information was available. Information from the National Board of Health and Welfare Centre for Epidemiology on date of death and death diagnosis was added to the database. In total 906,564 people were included, 50 percent foreign-born persons.

A Swedish matched control could not be found for 20,518 of the foreign-born persons due to the matching criteria. Exclusion criteria were as follows: if no information was available or if a person had emigrated or migrated back ("remigrated"), thus in total 163,896 persons were excluded from the database. Persons were then also excluded if the information from the control subject was missing due to migration. In total 182,614 persons, 109,458 men and 73,156 women, were excluded from the database; see Table 1 .

The largest group of excluded foreign- born persons, 45,228 persons, consisted of persons born in Finland. In the original database 44,067 of them were coded as migrated (remigrated) and mortality among 37,904 (86\%) of them could be analysed with data from the Population Register Centre in Finland. The analysis showed the same mortality risk among the excluded group as the Finnish-born persons who stayed in Sweden [6].

The database used for analysis finally consisted of 723,948 persons, 361,974 foreign-born and 361, 974 Swedish controls. Latest county of residence was used to distribute the study population in different geographical areas in Sweden. Mobility in Sweden between different counties showed a similar pattern. Among persons still living in 1990, 27.2\% 
of foreign-born and $25.5 \%$ of Swedes had lived in the same county during $1970-1990(P<0.001)$ and $81.1 \%$ versus $85.52 \%$ might have moved during the study period but were living the same county in 1990 as in 1970.

2.1. Characteristics of County Council Areas in Sweden. The 24 counties in Sweden differ with regard to population and area. The population varies from the largest one (Stockholm) with $1,860,872$ inhabitants to the smallest (Gotland) with 57,535 inhabitants (SCB, 2004). The four most densely populated counties are, as in 1970, Stockholm, Göteborg och Bohus, Malmöhus, and Östergötland. Gotland, Blekinge, Kronoberg, and Kalmar represent the less populated and could be considered as more rural counties according to the national classification [14]. The different counties also vary in terms of area, which tends to be larger in the north of Sweden, Norrbotten is the largest, covering an area of $98,249.5 \mathrm{~km}^{2}$. In contrast, the smallest county (Blekinge) has an area of $2,946.7 \mathrm{~km}^{2}$.

2.2. Statistical Analysis. Values from the total cohort sample are given as numbers, means, and percentages. Comparisons were made by tests of significance with Mann-Whitney $U$ test and Chi-square test. A value of $P<0.05$ was considered statistically significant [15]. Logistic regression analysis was performed and a model tested, adjusted for age and sex, with the two independent variables foreign-born and latest county of residence (categorical) and the dependent variable dead or alive. Uppsala County, with the lowest mortality, was used as reference.

Cox regression analysis was performed in two age groups: persons aged 60-69 years and 80 years or more. The analysis was adjusted for sex and age and tested the importance of being foreign born and latest county of residence (categorical). Uppsala was also in this analysis used as reference.

All analyses were performed using SPSS (Statistical Package for Social Sciences), version 11.5.

2.3. Ethics. Approval of the study was granted from the Ethics Committee of Lund University, Sweden, after a reviewing process from all other university ethics committees in Sweden.

\section{Results}

3.1. Characteristics of Counties and Differences in Mortality in relation to being a Foreign-Born Person. The study population was geographically distributed among the 24 different county council areas that made up the regional organization of Sweden in 1970. The major groups of foreign-born persons were found in the counties of Stockholm, Göteborg och Bohus, and Malmöhus; see Table 2. There were no significant differences between foreign- and Swedish-born persons in the different counties in relation to sex. In four counties (Stockholm, Göteborg \& Bohus, Västmanland, and Norrbotten), foreign-born persons had a significantly lower mean age than Swedish-born persons. The mean age was significantly higher among foreign-born men than Swedishborn men in eight and significantly lower in three counties. Foreign-born women had a higher mean age in nine and a lower mean age in three compared to Swedish-born women (Table 3).

During the studied period 1970-1999, a total of 116,063 foreign-born and 104,865 Swedish control persons had died. There was significant higher mortality for foreignborn persons than native Swedes in all counties with one exception, Norrbotten. The highest percentage of deceased among foreign-born persons was found in Gotland (43\%), Värmland (40.0\%), and Jämtland (37.4\%). The largest difference in deceased subjects, with higher mortality among foreign-born than Swedish-born persons, was found in the rural counties of Gotland (7.6\%), Blekinge (7.1\%), Kalmar (5.9\%), and Kronoberg (5.7\%).

3.2. Influence of Gender on Mortality. There was significant higher mortality in all counties for men and in 19 of the 24 counties for women (Tables $4(\mathrm{a})$ and 4(b)). The highest proportion of deceased foreign-born men was found in Gotland (49.7\%), Värmland (45.3\%), and Jämtland (41.3\%), see Table 4(a). The largest difference in percentage between deceased foreign- and Swedish-born male persons was in Gotland (11.4\%), Blekinge (9.0\%), Jämtland (7.9\%), and Jönköping (7.6\%). Foreign-born women had the highest percentage of deceased in Gotland (39.3\%), Värmland $(36.0 \%)$, and Norrbotten $(32.8 \%)$. The difference in percentage between foreign- and Swedish-born deceased female persons was largest in the rural counties of Kalmar $(5.3 \%)$, Blekinge (5.2\%), Kronoberg (4.8\%), and Gotland (4.7\%); see Table 4(b).

3.3. Influence of Age on Mortality. Mean age at time of death was significantly lower for foreign- than Swedish-born men in all counties, ranging from 1.0 to 4.4 years, except for Kalmar and Gotland (Table 5). For women significant differences in mean age at time of death were found in 19 counties. There was a larger difference in mean age at time of death between foreign- and Swedish-born men than between foreign- and Swedish-born women in all counties. Differences in survival time between foreign- and Swedish-born persons were studied in particular in two age groups of older persons, those aged 60-69 and 80+, using Cox regression analysis. In the age group 60-69 years, foreign-born persons had a significantly lower survival time in two counties, Norrbotten and Värmland. No difference was found in any of the other counties. In the age group $80+$ no significant differences were found.

3.4. Multifactorial Influence on Mortality. Logistic regression analysis studying the influence of being foreign-born and latest county of residence on mortality showed that being foreign-born was, adjusted for age and sex, an independent influencing factor $(P=0.000, B=0.242)$, as was county, except in four county council areas (Kronoberg, Kalmar, Kristianstad, Halland and Skaraborg) and the OR varied from 1.01 to 1.29 ; see Table 6 . 
TABle 2: Population in relation to sex and latest County Council of residence.

\begin{tabular}{|c|c|c|c|c|c|c|c|c|c|c|c|}
\hline \multirow[t]{2}{*}{ County council } & \multirow{2}{*}{$\begin{array}{c}\text { Proportion of foreign-born } \\
\text { of total population } 1970 \\
\%\end{array}$} & \multicolumn{2}{|c|}{ Men foreign-born } & \multicolumn{3}{|c|}{ Swedish-born } & \multicolumn{2}{|c|}{ Women foreign-born } & \multicolumn{3}{|c|}{ Swedish-born } \\
\hline & & $n$ & $\%$ & $n$ & $\%$ & $P$-value & $n$ & $\%$ & $n$ & $\%$ & $P$-value \\
\hline Stockholm & 10.5 & 50683 & 45.5 & 45955 & 45.1 & 0.218 & 60677 & 54.5 & 55986 & 54.9 & 0.278 \\
\hline Uppsala & 6.1 & 4016 & 46.5 & 4178 & 46.3 & 0.512 & 4614 & 53.5 & 4849 & 53.7 & 0.278 \\
\hline Södermanland & 9.5 & 7100 & 49.1 & 7271 & 49.6 & 0.658 & 7350 & 50.9 & 7394 & 50.4 & 0.663 \\
\hline Östergötland & 5.0 & 5444 & 47.8 & 6048 & 47.9 & 0.913 & 5942 & 52.2 & 6570 & 52.1 & 0.918 \\
\hline Jönköping & 5.1 & 4180 & 46.9 & 4593 & 47.1 & 0.868 & 4728 & 53.1 & 5153 & 52.9 & 0.878 \\
\hline Kronoberg & 5.0 & 2117 & 48.6 & 2626 & 49.8 & 0.504 & 2238 & 51.4 & 2649 & 50.2 & 0.513 \\
\hline Kalmar & 3.4 & 2352 & 48.5 & 2915 & 47.9 & 0.746 & 2502 & 51.5 & 3167 & 52.1 & 0.758 \\
\hline Gotland & 2.5 & 441 & 38.1 & 561 & 38.8 & 0.811 & 717 & 61.9 & 886 & 61.2 & 0.861 \\
\hline Blekinge & 5.1 & 1957 & 49.0 & 2329 & 49.7 & 0.701 & 2035 & 51.0 & 2354 & 50.3 & 0.706 \\
\hline Kristianstad & 3.8 & 3543 & 46.3 & 3832 & 46.1 & 0.876 & 4112 & 53.7 & 4484 & 53.9 & 0.888 \\
\hline Malmöhus & 7.3 & 17990 & 48.8 & 17002 & 48.6 & 0.778 & 18893 & 51.2 & 17984 & 51.4 & 0.785 \\
\hline Halland & 4.7 & 3583 & 46.8 & 3887 & 47.3 & 0.685 & 4079 & 53.2 & 4331 & 52.7 & 0.708 \\
\hline Göteborg och Bohus & 8.4 & 19041 & 50.5 & 18097 & 50.0 & 0.439 & 18664 & 49.5 & 18093 & 50.0 & 0.436 \\
\hline Älvsborg & 7.8 & 8761 & 44.7 & 9121 & 44.9 & 0.868 & 10827 & 55.3 & 11180 & 55.1 & 0.757 \\
\hline Skaraborg & 3.9 & 2966 & 46.2 & 3339 & 46.3 & 0.945 & 3452 & 53.8 & 3871 & 53.7 & 0.950 \\
\hline Värmland & 4.6 & 4365 & 43.5 & 4782 & 44.5 & 0.338 & 5681 & 56.5 & 5962 & 55.5 & 0.415 \\
\hline Örebro & 6.2 & 5148 & 48.7 & 5568 & 48.8 & 0.923 & 5418 & 51.3 & 5834 & 51.2 & 0.925 \\
\hline Västmanland & 11.6 & 8931 & 50.1 & 8653 & 50.6 & 0.602 & 8900 & 49.9 & 8457 & 49.4 & 0.599 \\
\hline Dalarna & 4.8 & 4805 & 48.4 & 5535 & 48.3 & 0.978 & 5126 & 51.6 & 5913 & 51.7 & 0.977 \\
\hline Gävleborg & 3.7 & 3468 & 49.0 & 4027 & 48.9 & 0.976 & 3611 & 51.0 & 4200 & 51.1 & 0.977 \\
\hline Västernorrland & 2.5 & 2365 & 44.1 & 2675 & 44.9 & 0.601 & 2996 & 55.9 & 3282 & 55.1 & 0.651 \\
\hline Jämtland & 2.3 & 973 & 39.2 & 1344 & 42.7 & 0.088 & 1511 & 60.8 & 1807 & 57.3 & 0.180 \\
\hline Västerbotten & 1.9 & 1323 & 35.7 & 1622 & 37.9 & 0.163 & 2383 & 64.3 & 2655 & 62.1 & 0.329 \\
\hline Norrbotten & 4.5 & 3150 & 31.6 & 2742 & 30.6 & 0.292 & 6816 & 68.4 & 6211 & 69.4 & 0.532 \\
\hline Total & & 168702 & & 168702 & & & 193272 & & 193272 & & \\
\hline
\end{tabular}

\section{Discussion}

The major findings in this study were that latest county of residence was an independent factor influencing mortality and that a variation with significantly higher mortality was found in all but one Swedish county among foreign-born persons compared with native Swedes. The highest difference compared to native controls of deceased foreign-born was found in counties with a more rural structure. Several factors might explain the noted differences, such as the size of the foreign-born population, differences in the healthcare system's ability to deliver healthcare, social network, stress, and economic resources.

\section{Strengths and Limitations}

The study of regional differences in mortality among foreignborn and native Swedes 1970-1999 was based on data from Statistics Sweden and from the National Board of Health and Welfare Centre for Epidemiology.

The data used to establish the database originated from the Population and Housing Census of 1970, which is considered to be a total census as it was compulsory by law to take part. The number of dropouts has not been estimated for the total census, only for some of the variables such as "occupation", which Statistics Sweden estimates to be $3.5-4.5 \%$. One can only speculate about whether participation in the census is related to health problems and whether dropout might differ between foreign-born and native healthy Swedes. It seems unlikely that the proportion of healthy foreign-born should be higher than native Swedes and thereby introduce selection bias. Another reason why migrants do not participate in the census could be language problems.

A Swedish matched control could not be found for 20,518 of the foreign-born persons due to the matching criteria. The geographical distribution of the excluded persons was not different from the distribution in the database used.

The excluded group varies in proportion with regard to country/region of birth. Excluded persons from Finland constitute the largest proportion $(30.8 \%)$. A followup of Finns who had remigrated was performed and showed no differences in mortality from the group of Finns included in the study [6]. Persons born in Finland constitute the largest group of migrants living in Sweden and were also the largest migrant group in the database used. There are no reasons to 
TABLe 3: Population in relation to age (1970) and latest county council of residence.

\begin{tabular}{|c|c|c|c|c|c|c|c|c|c|c|}
\hline \multirow{2}{*}{ County council } & \multicolumn{2}{|c|}{ Foreign-born men } & \multicolumn{3}{|c|}{ Swedish-born men } & \multicolumn{2}{|c|}{ Foreign-born women } & \multicolumn{3}{|c|}{ Swedish-born women } \\
\hline & Age (mean) & $95 \% \mathrm{CI}$ & Age (mean) & $95 \%$ CI & $P$ value & Age (mean) & $95 \% \mathrm{CI}$ & Age (mean) & $95 \%$ CI & $P$ value \\
\hline Stockholm & 39.9 & $39.8,40.0$ & 40.6 & $40.4,40.7$ & 0.000 & 43.0 & $42.9,43.2$ & 43.7 & $43.6,43.8$ & 0.000 \\
\hline Uppsala & 36.6 & $36.2,37.1$ & 36.7 & $36.2,37.1$ & 0.884 & 39.2 & $38.7,39.6$ & 39.0 & $38.6,39.4$ & 0.524 \\
\hline Södermanland & 38.5 & $38.2,38.8$ & 38.6 & $38.3,38.9$ & 0.670 & 40.0 & $39.7,40.4$ & 40.2 & $39.9,40.6$ & 0.487 \\
\hline Östergötland & 38.8 & $38.4,39.1$ & 38.1 & $37.7,38.4$ & 0.008 & 40.9 & $40.5,41.3$ & 40.4 & $40.0,40.7$ & 0.037 \\
\hline Jönköping & 38.3 & $37.8,38.7$ & 37.6 & $37.2,38.1$ & 0.026 & 40.5 & $40.0,40.9$ & 39.9 & $39.5,40.3$ & 0.029 \\
\hline Kronoberg & 39.0 & $38.4,39.7$ & 38.3 & $37.7,38.8$ & 0.088 & 40.9 & $40.3,41.6$ & 40.1 & $39.5,40.7$ & 0.055 \\
\hline Kalmar & 40.6 & $40.0,41.2$ & 39.0 & $38.4,39.5$ & 0.000 & 42.9 & $42.3,43.5$ & 41.0 & $40.4,41.5$ & 0.000 \\
\hline Gotland & 45.7 & $44.1,47.3$ & 42.6 & $41.2,44.0$ & 0.002 & 47.7 & $46.5,48.9$ & 44.6 & $43.5,45.8$ & 0.000 \\
\hline Blekinge & 39.4 & $38.8,40.1$ & 38.1 & $37.5,38.7$ & 0.001 & 42.1 & $41.3,42.8$ & 41.1 & $40.2,41.8$ & 0.068 \\
\hline Kristianstad & 40.6 & $40.1,41.0$ & 39.7 & $39.3,40.2$ & 0.009 & 42.6 & $42.1,43.1$ & 41.8 & $41.4,42.3$ & 0.022 \\
\hline Malmöhus & 39.7 & $39.5,40.0$ & 39.8 & $39.6,40.0$ & 0.725 & 42.5 & $42.3,42.8$ & 42.7 & $42.5,43.0$ & 0.377 \\
\hline Halland & 38.6 & $38.2,39.1$ & 38.2 & $37.7,38.6$ & 0.093 & 40.8 & $40.3,41.3$ & 40.1 & $39.7,40.6$ & 0.037 \\
\hline Göteborg och Bohus & 39.1 & $38.9,39.3$ & 39.5 & $39.3,39.7$ & 0.002 & 42.3 & $42.1,42.6$ & 42.6 & $42.4,42.9$ & 0.080 \\
\hline Älvsborg & 39.0 & $38.7,39.2$ & 38.7 & $38.4,39.0$ & 0.071 & 40.8 & $40.5,41.1$ & 40.6 & $40.3,40.9$ & 0.172 \\
\hline Skaraborg & 37.6 & $37.1,38.1$ & 37.0 & $36.5,37.5$ & 0.074 & 40.0 & $39.5,40.5$ & 39.4 & $38.9,39.9$ & 0.061 \\
\hline Värmland & 44.1 & $43.6,44.6$ & 43.0 & $42.6,43.5$ & 0.001 & 45.4 & $45.0,45.8$ & 44.8 & $44.3,45.2$ & 0.034 \\
\hline Örebro & 38.9 & $38.5,39.3$ & 38.6 & $38.2,38.9$ & 0.195 & 40.9 & $40.5,41.3$ & 40.5 & $40.1,40.9$ & 0.122 \\
\hline Västmanland & 37.7 & $37.4,38.0$ & 38.0 & $37.6,38.3$ & 0.138 & 39.0 & $38.7,39.3$ & 39.5 & $39.2,39.8$ & 0.009 \\
\hline Dalarna & 39.3 & $39.0,39.7$ & 39.0 & $38.7,39.4$ & 0.253 & 41.0 & $40.6,41.4$ & 40.5 & $40.2,40.9$ & 0.072 \\
\hline Gävleborg & 38.0 & $37.6,38.5$ & 37.6 & $37.2,38.0$ & 0.230 & 40.6 & $40.1,41.1$ & 39.8 & $39.4,40.3$ & 0.038 \\
\hline Västernorrland & 38.6 & $38.1,39.2$ & 38.5 & $38.0,39.0$ & 0.880 & 42.0 & $41.4,42.5$ & 41.5 & $40.9,42.0$ & 0.222 \\
\hline Jämtland & 42.8 & $41.9,43.8$ & 40.4 & $39.6,41.2$ & 0.000 & 44.1 & $43.3,44.8$ & 42.5 & $41.8,43.2$ & 0.002 \\
\hline Västerbotten & 37.8 & $37.0,38.6$ & 37.0 & $36.4,37.7$ & 0.389 & 41.4 & $40.8,42.0$ & 41.2 & $40.6,41.7$ & 0.625 \\
\hline Norrbotten & 38.8 & $38.3,39.3$ & 39.7 & $39.1,40.3$ & 0.022 & 43.5 & $43.1,43.9$ & 44.7 & $44.3,45.1$ & 0.000 \\
\hline
\end{tabular}

believe that "remigrants" born in other countries differ from the Finnish group.

Selection bias has to be considered. The excluded persons had a lower mean age than the persons in the database, with the exception of persons born in the former Yugoslavia, but their Swedish control person of the same age was also excluded. Only $8.1 \%$ of the excluded persons had reached the age of $60-69$ and $2.6 \%$ the age of $80+$. There is no reason to assume that the excluded persons influenced the survival analysis using these two age groups, due to the low proportion of excluded persons above 60 years of age.

Latest county of residence has been used as a variable. Migration within Sweden might have occurred and labour migration by healthier persons to urban areas could explain the higher mortality in rural counties. However, the pattern of internal migration within Sweden showed similarities between foreign-born and native Swedes. Among foreignborn persons still living in Sweden 1990, 53.9\% had changed county of residence during 1979-1999 but moved back to the same county 1990 as the one they lived in 1970, corresponding proportion for native Swedes was 60\%.

\section{Results}

The rural counties had in common that the proportion of foreign-born persons in their populations was low compared to the more urban counties. For some ethnic groups higher density in an area of persons from the same ethnic group has been shown to have a positive effect on self-rated health, limiting long-standing illness [16], and reduce odds of infants mortality [17]. Belonging to a small migrant group may be a risk factor; earlier studies have shown higher hospital rates for mental health problems in areas where migrants constitute a small proportion of the community [18]. The result has been interpreted as showing that if you belong to a larger migrant group it is likely that the stress connected with being a migrant could be reduced due to stronger social network [18]. Stress is also known to increase the susceptibility to other diseases such as diabetes and hypertension $[19,20]$. Furthermore, the ability of the healthcare systems, both hospitals and outpatient facilities, to handle and to investigate symptoms and signs among migrants is most likely to be poorer in counties with few migrants. It could be hypothesized that delay or misunderstanding in diagnosis and treatment and healthcare staff with insufficient "language skills" and understanding of cultural differences could influence mortality. In a previous study it was shown that symptoms, signs, and ill-defined condition were more common as cause of death among foreign-born compared to native Swedish persons [7].

Another explanatory factor could be differences in social networks in different geographical areas [21]. Poor social 
TABle 4: (a) Deceased men in relation to latest county council of residence, (b) Deceased women in relation to latest to county council of residence.

(a)

\begin{tabular}{|c|c|c|c|c|c|c|}
\hline \multirow{2}{*}{ County council } & \multicolumn{2}{|c|}{ Foreign-born men } & \multicolumn{2}{|c|}{ Swedish-born men } & \multirow[b]{2}{*}{$P$-value } & \multirow[b]{2}{*}{$\%$ difference } \\
\hline & $n$ & $\%$ & $n$ & $\%$ & & \\
\hline Gotland & 219 & 49.7 & 215 & 38.3 & 0.000 & 11.4 \\
\hline Blekinge & 697 & 35.6 & 620 & 26.6 & 0.000 & 9.0 \\
\hline Jämtland & 402 & 41.3 & 449 & 33.4 & 0.000 & 7.9 \\
\hline Jönköping & 1366 & 32.7 & 1155 & 25.1 & 0.000 & 7.6 \\
\hline Västernorrland & 809 & 34.2 & 723 & 27.0 & 0.000 & 7.2 \\
\hline Kronoberg & 700 & 33.1 & 686 & 26.1 & 0.000 & 7.0 \\
\hline Älvsborg & 3060 & 34.9 & 2542 & 27.9 & 0.000 & 7.0 \\
\hline Örebro & 1776 & 34.5 & 1553 & 27.9 & 0.000 & 6.6 \\
\hline Östergötland & 1821 & 33.4 & 1632 & 27.0 & 0.000 & 6.4 \\
\hline Kalmar & 830 & 35.3 & 841 & 28.9 & 0.000 & 6.4 \\
\hline Stockholm & 18214 & 39.9 & 15613 & 34.0 & 0.000 & 5.9 \\
\hline Värmland & 1976 & 45.3 & 1899 & 39.7 & 0.000 & 5.6 \\
\hline Södermanland & 2482 & 35.0 & 2142 & 29.5 & 0.000 & 5.5 \\
\hline Kristianstad & 1214 & 34.3 & 1105 & 28.8 & 0.000 & 5.5 \\
\hline Skaraborg & 891 & 30.0 & 829 & 24.8 & 0.000 & 5.2 \\
\hline Dalarna & 1668 & 34.7 & 1634 & 29.5 & 0.000 & 5.2 \\
\hline Halland & 1077 & 30.1 & 981 & 25.2 & 0.000 & 4.9 \\
\hline Gävleborg & 1149 & 33.1 & 1134 & 28.2 & 0.000 & 4.9 \\
\hline Göteborg och Bohus & 6816 & 35.8 & 5610 & 31.0 & 0.000 & 4.8 \\
\hline Västerbotten & 392 & 29.6 & 422 & 26.0 & 0.029 & 3.6 \\
\hline Malmöhus & 6311 & 35.1 & 5354 & 31.5 & 0.000 & 3.6 \\
\hline Västmanland & 2737 & 30.6 & 2343 & 27.1 & 0.000 & 3.5 \\
\hline Uppsala & 1117 & 27.8 & 1026 & 24.6 & 0.001 & 3.2 \\
\hline Norrbotten & 1096 & 34.8 & 883 & 32.2 & 0.036 & 2.6 \\
\hline Total & 58820 & & 51391 & & & \\
\hline
\end{tabular}

(b)

\begin{tabular}{|c|c|c|c|c|c|c|}
\hline \multirow{2}{*}{ County council } & \multicolumn{2}{|c|}{ Foreign-born women } & \multicolumn{2}{|c|}{ Swedish-born women } & \multirow[b]{2}{*}{$P$-value } & \multirow[b]{2}{*}{$\%$ difference } \\
\hline & $n$ & $\%$ & $n$ & $\%$ & & \\
\hline Kalmar & 770 & 30.8 & 807 & 25.5 & 0.000 & 5.3 \\
\hline Blekinge & 640 & 31.4 & 617 & 26.2 & 0.000 & 5.2 \\
\hline Kronoberg & 617 & 27.6 & 604 & 22.8 & 0.000 & 4.8 \\
\hline Gotland & 282 & 39.3 & 301 & 34.0 & 0.027 & 4.7 \\
\hline Kristianstad & 1239 & 30.1 & 1155 & 25.8 & 0.000 & 4.3 \\
\hline Jönköping & 1220 & 25.8 & 1152 & 22.4 & 0.000 & 3.4 \\
\hline Älvsborg & 3009 & 27.8 & 2768 & 24.8 & 0.000 & 3.0 \\
\hline Gävleborg & 982 & 27.2 & 1015 & 24.2 & 0.002 & 3.0 \\
\hline Östergötland & 1647 & 27.7 & 1632 & 24.8 & 0.000 & 2.9 \\
\hline Malmöhus & 5791 & 30.7 & 5014 & 27.9 & 0.000 & 2.8 \\
\hline Halland & 1028 & 25.2 & 977 & 22.6 & 0.004 & 2.6 \\
\hline Västerbotten & 669 & 28.1 & 681 & 25.6 & 0.052 & 2.5 \\
\hline Örebro & 1483 & 27.4 & 1466 & 25.1 & 0.007 & 2.3 \\
\hline Dalarna & 1397 & 27.3 & 1478 & 25.0 & 0.007 & 2.3 \\
\hline Göteborg och Bohus & 5723 & 30.7 & 5200 & 28.7 & 0.000 & 2.0 \\
\hline Uppsala & 1099 & 23.8 & 1057 & 21.8 & 0.019 & 2.0 \\
\hline Västernorrland & 905 & 30.2 & 925 & 28.2 & 0.078 & 2.0 \\
\hline Värmland & 2046 & 36.0 & 2040 & 34.2 & 0.042 & 1.8 \\
\hline Södermanland & 1954 & 26.6 & 1846 & 25.0 & 0.025 & 1.6 \\
\hline Skaraborg & 843 & 24.4 & 887 & 22.9 & 0.130 & 1.5 \\
\hline
\end{tabular}


(b) Continued.

\begin{tabular}{|c|c|c|c|c|c|c|}
\hline \multirow{2}{*}{ County council } & \multicolumn{2}{|c|}{ Foreign-born women } & \multicolumn{2}{|c|}{ Swedish-born women } & \multirow[b]{2}{*}{$P$-value } & \multirow[b]{2}{*}{$\%$ difference } \\
\hline & $n$ & $\%$ & $n$ & $\%$ & & \\
\hline Norrbotten & 2235 & 32.8 & 2090 & 33.6 & 0.298 & 0.8 \\
\hline Stockholm & 19140 & 31.5 & 17289 & 30.9 & 0.015 & 0.6 \\
\hline Västmanland & 2065 & 23.2 & 1927 & 22.8 & 0.515 & 0.4 \\
\hline Jämtland & 459 & 30.4 & 546 & 30.2 & 0.920 & 0.2 \\
\hline Total & 57243 & & 53474 & & & \\
\hline
\end{tabular}

TABLE 5: Deceased in relation to age at time of death and latest county council of residence.

\begin{tabular}{|c|c|c|c|c|c|c|c|c|c|c|}
\hline \multirow{2}{*}{ County council } & \multicolumn{2}{|c|}{ Foreign-born men } & \multicolumn{3}{|c|}{ Swedish-born men } & \multicolumn{2}{|c|}{ Foreign-born women } & \multicolumn{3}{|c|}{ Swedish-born women } \\
\hline & Age (mean) & $95 \% \mathrm{CI}$ & Age (mean) & $95 \%$ CI & $P$-value & Age (mean) & $95 \%$ CI & Age (mean) & $95 \%$ CI & $P$-value \\
\hline Stockholm & 67.5 & $67.3,67.7$ & 70.6 & $70.4,70.8$ & 0.000 & 75.0 & $74.8,75.2$ & 76.9 & $76.7,77.1$ & 0.000 \\
\hline Uppsala & 66.0 & $65.1,66.8$ & 69.1 & $68.2,70.0$ & 0.000 & 73.7 & $72.9,74.5$ & 75.2 & $74.4,76.0$ & 0.004 \\
\hline Södermanland & 65.7 & $65.2,66.3$ & 70.1 & $69.5,70.6$ & 0.000 & 72.6 & $72.0,73.2$ & 74.8 & $74.2,75.4$ & 0.000 \\
\hline Östergötland & 66.2 & $65.5,66.9$ & 70.5 & $69.9,71.1$ & 0.000 & 73.5 & $72.8,74.2$ & 75.1 & $74.4,75.7$ & 0.002 \\
\hline Jönköping & 66.3 & $65.6,67.1$ & 70.2 & $69.5,71.0$ & 0.000 & 72.9 & $72.1,73.7$ & 74.2 & $73.4,75.0$ & 0.013 \\
\hline Kronoberg & 68.5 & $67.4,69.5$ & 71.5 & $70.6,72.5$ & 0.000 & 73.3 & $72.1,74.4$ & 75.5 & $74.5,76.5$ & 0.008 \\
\hline Kalmar & 68.7 & $67.7,69.7$ & 70.4 & $69.6,71.3$ & 0.060 & 75.5 & $74.6,76.4$ & 75.8 & $75.0,76.7$ & 0.626 \\
\hline Gotland & 72.4 & $70.7,74.1$ & 73.6 & $71.9,75.2$ & 0.310 & 78.0 & $76.6,79.3$ & 77.9 & $76.6,79.3$ & 0.979 \\
\hline Blekinge & 67.9 & $66.9,68.9$ & 71.3 & $70.3,72.3$ & 0.000 & 74.4 & $73.3,75.5$ & 76.6 & $75.7,77.6$ & 0.005 \\
\hline Kristianstad & 69.7 & $68.9,70.4$ & 72.2 & $71.5,72.9$ & 0.000 & 74.9 & $74.2,75.7$ & 76.8 & $76.1,77.5$ & 0.001 \\
\hline Malmöhus & 67.9 & $67.5,68.2$ & 70.6 & $70.3,70.9$ & 0.000 & 74.4 & $74.1,74.8$ & 76.7 & $76.4,77.1$ & 0.000 \\
\hline Halland & 67.8 & $67.1,68.6$ & 70.7 & $69.9,71.6$ & 0.000 & 74.4 & $73.5,75.2$ & 76.3 & $75.5,77.1$ & 0.001 \\
\hline Göteborg och Bohus & 65.9 & $65.5,66.2$ & 69.7 & $69.3,70.0$ & 0.000 & 73.9 & $73.6,74.3$ & 76.0 & $75.7,76.3$ & 0.000 \\
\hline Älvsborg & 67.1 & $66.6,67.7$ & 71.3 & $70.8,71.8$ & 0.000 & 73.9 & $73.5,74.4$ & 76.1 & $75.6,76.6$ & 0.000 \\
\hline Skaraborg & 67.0 & $66.0,67.9$ & 70.5 & $69.7,71.4$ & 0.000 & 73.4 & $72.4,74.3$ & 74.6 & $73.8,75.4$ & 0.105 \\
\hline Värmland & 70.3 & $69.8,70.9$ & 72.7 & $72.2,73.2$ & 0.000 & 75.5 & $75.0,76.1$ & 76.8 & $76.3,77.3$ & 0.001 \\
\hline Örebro & 66.6 & $65.9,67.2$ & 70.2 & $69.5,70.8$ & 0.000 & 72.3 & $71.7,73.0$ & 74.0 & $73.4,74.7$ & 0.000 \\
\hline Västmanland & 65.7 & $65.2,66.2$ & 69.5 & $69.0,70.0$ & 0.000 & 71.8 & $71.2,72.3$ & 73.0 & $72.4,73.6$ & 0.002 \\
\hline Dalarna & 66.6 & $65.9,67.2$ & 70.8 & $70.2,71.4$ & 0.000 & 72.5 & $71.8,73.2$ & 74.2 & $73.5,74.8$ & 0.001 \\
\hline Gävleborg & 64.8 & $64.0,65.6$ & 68.6 & $67.9,69.3$ & 0.000 & 72.6 & $71.7,73.4$ & 74.5 & $73.7,75.2$ & 0.005 \\
\hline Västernorrland & 66.4 & $65.5,67.3$ & 70.4 & $69.5,71.3$ & 0.000 & 73.7 & $72.8,74.5$ & 74.2 & $73.4,75.1$ & 0.340 \\
\hline Jämtland & 70.3 & $69.0,71.6$ & 71.3 & $70.1,72.4$ & 0.000 & 75.3 & $74.2,76.5$ & 74.8 & $73.8,75.8$ & 0.558 \\
\hline Västerbotten & 67.7 & $66.3,69.1$ & 70.0 & $68.8,71.2$ & 0.003 & 72.4 & $71.4,73.4$ & 74.4 & $73.5,75.3$ & 0.008 \\
\hline Norrbotten & 67.1 & $66.3,67.9$ & 70.8 & $70.0,71.6$ & 0.000 & 74.7 & $74.2,75.2$ & 76.0 & $75.5,76.5$ & 0.000 \\
\hline
\end{tabular}

network and low social support are more common among foreign-born persons [22] and have been shown to influence and increase mortality [23].

Generally no significantly higher mortality among migrants was found in Norrbotten, but mortality was higher for men when men and women were analysed separately.

This county has close cultural contacts with Finland [24] and many inhabitants are bilingual. A short cultural distance between migrants and native population has been described as important for health [25].

The differences in mortality in all Swedish counties, with one exception, among foreign-born persons compared with native Swedes could indicate differences in economic resources and needs in the population. One measure of economic resources in the county was the local tax rate. In the middle of the studied period (1985), local tax per unit differed from $28.46 \%$ (Kristianstad) to $32.00 \%$ in Blekinge of taxable income [26], although the taxation differences were also equalized by a national taxation transfer system [27]. Whether differences in economic resources between counties might influence the noted mortality differences in relation to foreign-born persons requires further analysis.

More healthcare needs are connected with an elderly population [10] and in 1985 the share of the population aged 80 years or more in the counties varied from $2.7 \%$ to $4.2 \%$ [27]. The lowest percentage for this age group was found in Norrbotten. The counties of Gotland and Blekinge, with the largest proportion of deceased foreign-born persons, were also characterized in 1985 by a low percentage of foreignborn persons $(2.3 \%$ and $5.1 \%)$ and average or higher than average percentage of the population 80 aged years or more (3.8\% and $3.9 \%)$.

There are a strong connection between increased mortality and increased age $[9,10,12]$. A higher mean age in 
TABLE 6: Multifactorial influence of being foreign-born on mortality adjusted for age and gender with latest county council of residence as independent categorical variable using Uppsala county council as reference.

\begin{tabular}{|c|c|c|c|c|c|}
\hline County council & $B$-value & SE & $P$-value & OR & $95 \%$ CI for Exp. $B$ \\
\hline Stockholm & 0.180 & 0.023 & 0.000 & 1.197 & $1.144,1.253$ \\
\hline Södermanland & 0.197 & 0.028 & 0.000 & 1.218 & $1.154,1.286$ \\
\hline Östergötland & 0.116 & 0.029 & 0.000 & 1.123 & $1.061,1.189$ \\
\hline Jönköping & 0.063 & 0.031 & 0.041 & 1.065 & $1.003,1.131$ \\
\hline Kronoberg & 0.013 & 0.037 & 0.736 & 1.013 & $0.941,1.089$ \\
\hline Kalmar & 0.062 & 0.035 & 0.079 & 1.064 & $0.993,1.140$ \\
\hline Gotland & 0.194 & 0.059 & 0.001 & 1.214 & $1.081,1.362$ \\
\hline Blekinge & 0.113 & 0.038 & 0.003 & 1.119 & $1.038,1.206$ \\
\hline Kristianstad & 0.022 & 0.032 & 0.482 & 1.023 & $0.961,1.089$ \\
\hline Malmöhus & 0.157 & 0.025 & 0.000 & 1.170 & $1.115,1.228$ \\
\hline Halland & -0.053 & 0.032 & 0.099 & 0.948 & $0.890,1.010$ \\
\hline Göteborg och Bohus & 0.210 & 0.025 & 0.000 & 1.233 & $1.175,1.294$ \\
\hline Älvsborg & 0.106 & 0.027 & 0.000 & 1.112 & $1.055,1.172$ \\
\hline Skaraborg & 0.047 & 0.034 & 0.159 & 1.049 & $0.982,1.120$ \\
\hline Värmland & 0.255 & 0.029 & 0.000 & 1.291 & $1.218,1.367$ \\
\hline Örebro & 0.158 & 0.029 & 0.000 & 1.171 & $1.106,1.240$ \\
\hline Västmanland & 0.087 & 0.027 & 0.001 & 1.091 & $1.035,1.151$ \\
\hline Dalarna & 0.157 & 0.029 & 0.000 & 1.170 & $1.105,1.239$ \\
\hline Gävleborg & 0.215 & 0.032 & 0.000 & 1.240 & $1.165,1.319$ \\
\hline Västernorrland & 0.186 & 0.034 & 0.000 & 1.204 & $1.125,1.288$ \\
\hline Jämtland & 0.194 & 0.043 & 0.000 & 1.214 & $1.116,1.321$ \\
\hline Västerbotten & 0.126 & 0.039 & 0.001 & 1.134 & $1.051,1.224$ \\
\hline Norrbotten & 0.230 & 0.030 & 0.000 & 1.259 & $1.187,1.336$ \\
\hline
\end{tabular}

the foreign-born population could also explain the larger proportion of deceased foreign-born women in two counties (Kalmar and Gotland) but was not found in the counties of Kronoberg and Blekinge. Furthermore, the variation in mortality between counties with higher mortality among foreign-born remained after adjustment for age and gender.

Other explanatory factors could be work environment and type of employment. Foreign-born men have to a higher degree been employed in private manufacturing industry, which is often found in rural counties like Kronoberg, Kalmar, and Blekinge [28]. Foreign-born women in Sweden could to a higher extent be exposed to shift work and physical and stressful work $[29,30]$.

In most counties and especially for men, the mean age at time of death is lower among foreign-born persons than native Swedes. The mean age at time of death of foreignborn men in the two counties Norrbotten and Värmland with highest OR was 2.4 to 3.7 years lower than native Swedes and correspondingly 1.3 to 1.8 years lower for women. Cox regression analysis also confirms a lower survival time for foreign-born persons in the counties of Norrbotten and Värmland for the age group 60-69.

\section{Conclusion}

In conclusion, county of residence influences mortality, and the study indicates a tendency to higher mortality among foreign-born persons than native Swedes in counties with a more rural structure. Further studies are needed to explore possible explanations and to establish the county-specific characteristics to explain variations between county council areas.

\section{Acknowledgments}

This work was supported by grants from the research profile AMERY (labour market, migration, and ethnic relations) Växjö University, Sweden, the KIP Pension \& Forsaking (The Pension Insurance Institute of the Co-operative Societies), Sweden, and Rådet för Hälos-och sjukvårdsforskning $\mathrm{i}$ södra Sverige HSF (the Council for Health and HealthCare Research in Southern Sweden).

\section{References}

[1] N. Brimblecombe, D. Dorling, and M. Shaw, "Migration and geographical inequalities in health in Britain," Social Science \& Medicine, vol. 50, no. 6, pp. 861-878, 2000.

[2] G. Caselli, L. Cerbara, F. Heins, and R. M. Lipsi, "What impact do contextual variables have on the changing geography of mortality in Italy?" European Journal of Population, vol. 19, no. 4, pp. 339-373, 2003.

[3] R. Maheswaran, D. P. Strachan, B. Dodgeon, and N. G. Best, "A population-based case-control study for examining early life influences on geographical variation in adult mortality 
in England and Wales using stomach cancer and stroke as examples," International Journal of Epidemiology, vol. 31, no. 2, pp. 375-382, 2002.

[4] T. H. Limtanakool, "Unequal treatment linked to thousands of minority deaths," The Nation's Health, vol. 4, p. 6, 2005.

[5] R. Mitchell, D. Dorling, and M. Shaw, "Population production and modelling mortality-an application of geographic information systems in health inequalities research," Health \& Place, vol. 8, no. 1, pp. 15-24, 2002.

[6] B. Albin, K. Hjelm, J. Ekberg, and S. Elmståhl, "Mortality among 723948 foreign- and native-born Swedes 1970-1999," European Journal of Public Health, vol. 15, no. 5, pp. 511-517, 2005a.

[7] B. Albin, K. Hjelm, J. Ekberg, and S. Elmståhl, "Higher mortality and different pattern of causes of death among foreignborn compared to native Swedes 1970-1999," Journal of Immigrant and Minority Health, vol. 8, no. 2, pp. 101-113, 2006.

[8] B. Albin, K. Hjelm, J. Ekberg, and S. Elmståhl, "Utilization of health care among foreign-born compared to native Swedes 1987-1999," . In press.

[9] National Board of Health and Welfare, "Causes of Death 2001,” (Dödsorsaker 2001), http://www.socialstyrelsen.se/Lists/ Artikelkatalog/Attachments/10829/2003-42-5_2003425.pdf.

[10] National Board of Health and Welfare, Sweden's Public Health Report 2005, National Board of Health and Welfare, Stockholm, Sweden, 2005.

[11] S. Elmståhl, "Sjukvård på lika villkor? (Health care on equal terms?)," in Malmö: Geriatriskt Utvecklingscentrum Universitetssjukhuset MAS, pp. 1-38, Media-Tryck, 2005.

[12] SCB, Statistisk årsbok för Sverige 2004 (Statistical Yearbook for Sweden 2004), Statistiska centralbyrån, Stockholm, Sweden, 2003.

[13] SFS 1982:763, The Swedish Health and Medical Service Act 1982:763, Ministry of Health and Social Affairs, Stockholm, Sweden, 1982, http://www.notisum.se/rnp/sls/lag/19820763 .htm.

[14] Swedish Association of Local Authorities and regions (SALAR), "Classification of municipalities," 2005, http://www .scb.se/Grupp/Hitta_statistik/Regional\%20statistik/Kartor/_ Dokument/SKL_kommungrp.pdf.

[15] D. Altman, Practical Statistics for Medical Research, Chapman \& Hall, London, UK, 1991.

[16] K. E. Pickett, R. J. Shaw, K. Atkin, K. E. Kiernan, and R. G. Wilkinson, "Ethnic density effects on maternal and infant health in the Millennium Cohort Study," Social Science \& Medicine, vol. 69, no. 10, pp. 1476-1483, 2009.

[17] R. J. Shaw, K. E. Pickett, and R. G. Wilkinson, "Ethnic density effects on birth outcomes and maternal smoking during pregnancy in the US linked birth and infant death data set," American Journal of Public Health, vol. 100, no. 4, pp. 707-713, 2010.

[18] D. Hull, "Migration, adaptation, and illness: a review," Social Science \& Medicine, vol. 13, no. 1, pp. 25-36, 1979.

[19] E. E. Agardh, A. Ahlbom, T. Andersson et al., "Work stress and low sense of coherence is associated with type 2 diabetes in middle-aged Swedish women," Diabetes Care, vol. 26, no. 3, pp. 719-724, 2003.

[20] P. Björntorp, "Do stress reactions cause abdominal obesity and comorbidities?" Obesity Reviews, vol. 2, no. 2, pp. 73-86, 2001.

[21] H. Mollenkopf and R. Kaspar, "Ageing in rural areas of East and West Germany: increasing similarities and remaining differences," European Journal of Ageing, vol. 2, no. 2, pp. 120130, 2005.
[22] J. Sundquist, E. Iglesias, and Å. Isacsson, "Migration and health. A study of Latin American refugees, their exile in Sweden and repatriation," Scandinavian Journal of Primary Health Care, vol. 13, no. 2, pp. 135-140, 1995.

[23] B. S. Hanson, S. O. Isacsson, L. Janzon, and S. E. Lindell, "Social network and social support influence mortality in elderly men. The prospective population study of "men born in 1914", Malmo, Sweden," American Journal of Epidemiology, vol. 130, no. 1, pp. 100-111, 1989.

[24] I. Svanberg and M. Tydén, Tusen år av invandring (A Thousand Years of Immigration), Dialogos, Stockholm, Sweden, 2005.

[25] K. Hjelm, J. Apelqvist, P. Nyberg, J. Sundquist, and A. Isacsson, "Health, health care utilization and living conditions in foreign-born diabetic patients in southern Sweden," Journal of Internal Medicine, vol. 242, no. 2, pp. 131-141, 1997.

[26] SCB, Statistisk årsbok för Sverige 1986 (Statistical Yearbook for Sweden 1986), Statistiska centralbyrån, Stockholm, Sweden, 1985.

[27] SOU 1998:51, Kostnadsutjämning för kommuner och landsting (Equalizations of Costs for Local Authorities and County Councils. Government Report), Norstedts Tryckeri, Stockholm, Sweden, 1998.

[28] SOU 2004:21, Egenförsörjning eller bidragsförsörjning (Living off Your Work or on Allowance. Government report), Fritzes Offentliga Publikationer, Stockholm, Sweden, 2004.

[29] J. Ekberg, "Economic progress of immigrants in Sweden from 1970 to 1990: a longitudinal study," Scandinavian Journal of Social Welfare, vol. 3, no. 3, pp. 148-115, 1994.

[30] R. Rosmond, L. Lapidus, and P. Björntorp, "A comparative review of psychosocial and occupational environment in native Swedes and immigrants," Scandinavian Journal of Public Health, vol. 24, no. 4, pp. 237-242, 1996. 


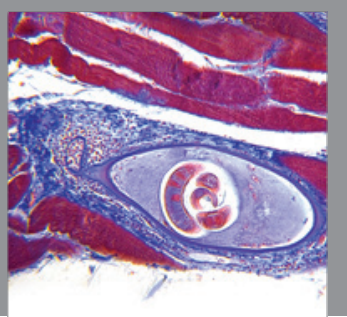

Gastroenterology

Research and Practice
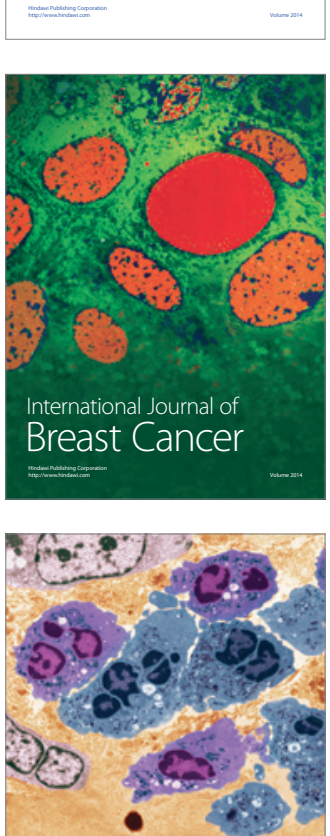

International Journal of Inflammation
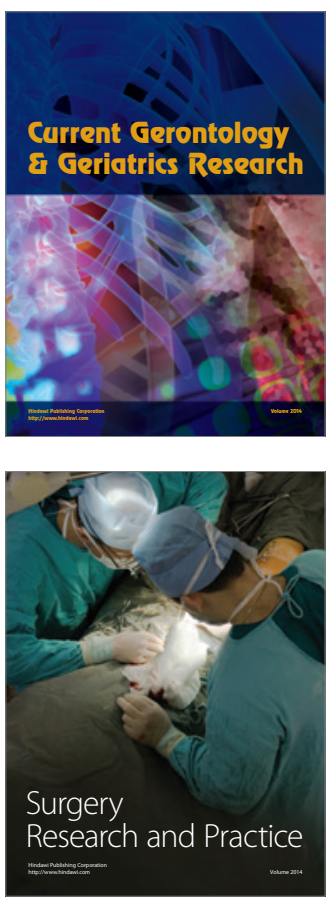
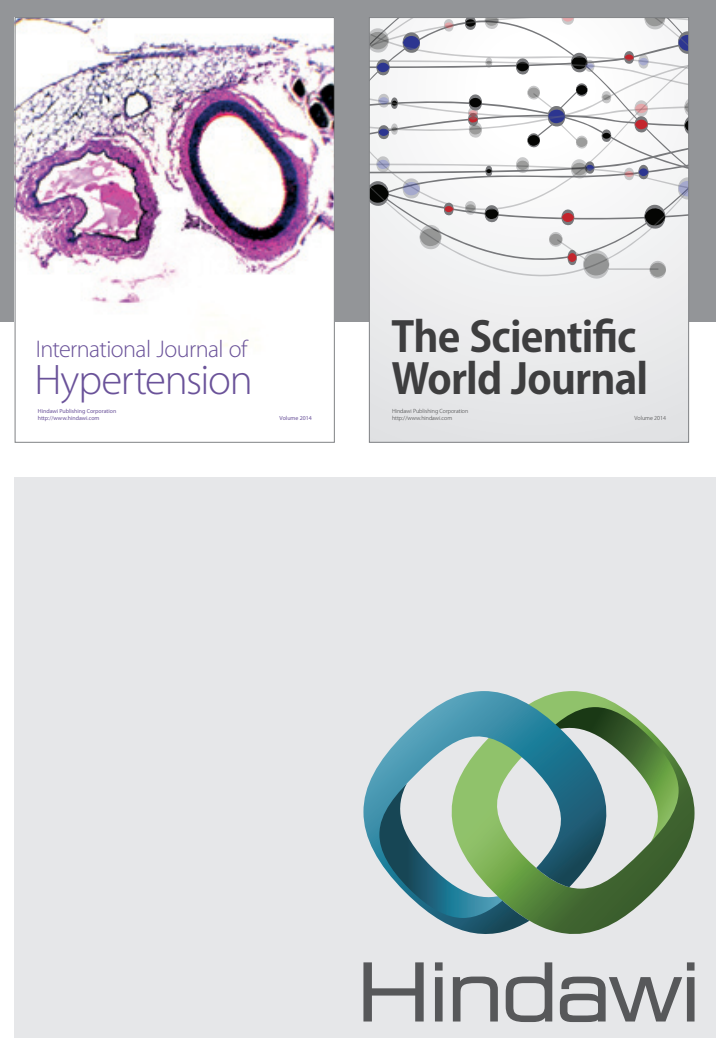

Submit your manuscripts at

http://www.hindawi.com
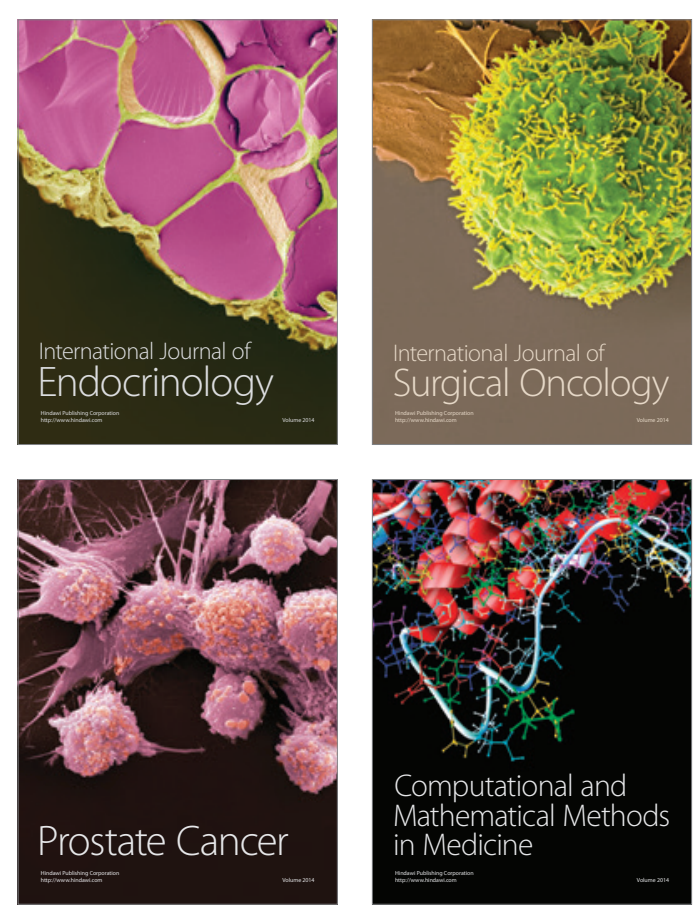
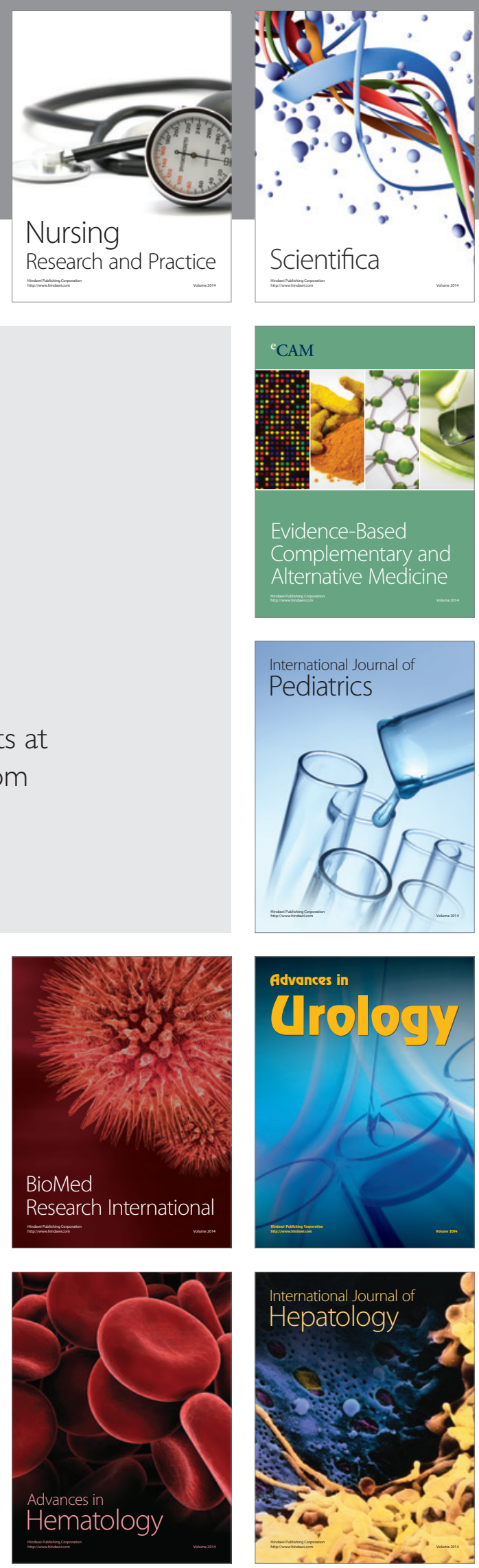